\title{
Association of Pre-procedural High Sensitivity C-Reactive Protein with In-hospital Outcome of Patients Undergoing Percutaneous Coronary Intervention
}

\author{
Jannat $\mathrm{S}^{1}$, Akanda MAK ${ }^{1}$, Khalequzzaman $\mathrm{M}^{1}$, Ullah $\mathrm{M}^{1}$, Monirujjaman $\mathrm{M}^{2}$, Islam $\mathrm{MJ}^{1}$ \\ ${ }^{1}$ Department of Cardiology, National Institute of Cardivascular Diseases, Dhaka, Bangladesh \\ ${ }^{2}$ Department of Cardiology, Khwaza Yunus Ali Medical College and Hospital, Sirajganj, Bangladesh
}

e-mail:drsufiajannat@gmail.com

\begin{abstract}
Emerging evidence links an elevated baseline inflammatory status to adverse outcome among patients undergoing percutaneous coronary intervention (PCI). Baseline inflammation measured by high sensitivity C-reactive protein hsCRP may prove useful for identification of high risk patients requiring adjunctive therapies. This prospective study was carried out in the department of cardiology, National Institute of Cardiovascular Diseases, Dhaka, during October 2012 to September 2013.Two hundred consecutive patients with CSA and UA undergoing PCI were included in the study. Study patients were divided into two groups on the basis of hsCRP levels. In Group I hsCRP levels were elevated, that is $\geq 3 \mathrm{mg} / \mathrm{L}$ and in Group II hsCRP levels were normal, that is $<3 \mathrm{mg} / \mathrm{L}$, with 100 patients in each group. Following the procedure in-hospital outcome of study patients were observed. Increased incidence (44\%) of adverse in-hospital outcome was found in Group I (44\% Vs. 11\%). Higher incidence of post procedural angina (17\%), peri-procedural myocardial infarction $(6 \%)$ and peri-procedural myocardial injury $(10 \%)$ was observed in this group. Nonsignificant rate of acute myocardial infarction, significant arrhythmia, acute LVF, cardiogenic shock and death were found in elevated hsCRP Group. Overall Major Adverse Cardiac Events (6\% Vs. 0\%) were found in pre-procedural elevated hsCRP group. High sensitivity C-reactive protein remained independently predictive of adverse in-hospital outcome, with 95\% CI of RR $1.4-4.4$ and $p<001$. The present study concludes that the hsCRP is an important and independent predictor of adverse in hospital outcome.
\end{abstract}

Key words: High sensitivity C-reactive protein (hsCRP), In-hospital outcome, percutaneous coronary intervention.

\section{Introduction}

Percutaneous coronary intervention (PCI) is an established myocardial revascularization procedure. There are some definite complications of PCI. With the evolving scientific knowledge of underlying pathophysiology of post procedural complications, emerging predictors are being searched. Conventionally, clinical and angiographic lesion classifications have served to identify high-risk patients undergoing PCI. ${ }^{1-3}$

Emerging evidence links an elevated baseline inflammatory status to adverse outcomes among patients undergoing PCI. In vitro, enhanced cy- tokine synthesis by peripheral blood monocytes before PCI has been found to predict late lumen loss, suggesting that pre-procedural activation of inflammatory cells may play a role in the modulation of vessel wall response to the injury induced by balloon PCI. ${ }^{4}$ This possibility is supported by experimental and clinical studies showing that acute phase reactants and proinflammatory cytokines promote leukocyte, endothelial and smooth muscle cell activation, resulting in an increase in pro coagulant activity, metalloproteinase release and neo intimal proliferation. C-reactive protein (CRP), serum amyloid A protein (SAA) and fibrinogen are easily meas- 
urable acute-phase reactants, which are synthesized in response to pro inflammatory cytokines. ${ }^{5}$

Since the last decade, biochemical markers have been carefully investigated; among these, several markers have been related to the risk of death, myocardial infarction, or restenosis after PCI, but only CRP has been shown to significantly and independently confer an adverse prognosis in patients with coronary artery disease, including those undergoing PCI.6,7 This is probably because of its relatively long half-life and chemical stability as well as the limited costs and logistic hurdles. ${ }^{7}$

C-reactive protein is an easily measurable acute phase reactant synthesized by hepatocytes in response to pro-inflammatory cytokines, predominantly interleukin-6. ${ }^{8}$ High sensitivity C-reactive protein (hsCRP) assay has a range of measurement that extends below the measurement range typical of most conventional CRP assay. As an inflammatory marker CRP increases procoagulant activity, risk of distal embolisation or may augment microvascular inflammation after ischemic insult during PCI that might be responsible for post procedural ischemic complication. ${ }^{9}$

Increased high sensitivity CRP may become an important factor in pre-procedural risk stratification. As an independent marker for the rapid progression of atherosclerosis or the presence of an increased risk of subsequent adverse clinical outcome, increased hsCRP may identify high-risk patients as candidates for high dose lipid lowering therapy. ${ }^{10}$

A focus on baseline inflammation measured by hsCRP may prove useful for identification of high risk patients who might benefit from adjunctive pharmacological and mechanical therapy during the procedure.

\section{Materials and Methods}

Patient's selection and data collection: The current prospective observational study included 200 patients of chronic stable angina and unstable angina and who underwent PCI between October 2012 to September 2013, in the National Institute of Cardiovascular Diseases (NICVD), Dhaka. Patients having total occlusion, left main disease, triple vessel disease, history of MI, Left ventricular ejection fraction $(\mathrm{LVEF}) \leq 30 \%$, inter- current inflammatory condition, treatment with steroid, immunosuppressive drugs, NSAID except low dose aspirin were excluded from the study. Baseline data included, demographic profile, ischemic heart disease status, LVEF, number of diseased vessels, American College of Cardiology/American Heart Association (ACC/AHA) lesion classification. Baseline hsCRP levels were measured routinely on the day before PCI by latex-enhanced immune nephelometry on a Behring BN-Pro Spec Nephelometer (SIEMENS, USA). Subjects were divided into two groups according to hsCRP level. Group I included 100 patients with elevated hsCRP level $(\geq 3 \mathrm{mg} / \mathrm{dl})$ and Group II included 100 patients with normal hsCRP level $(<3 \mathrm{mg} / \mathrm{dl})$. The study protocol was approved by the institutional ethical committee.

Procedures were performed using standard PCI technique in significant coronary lesion $(\geq 50 \%$ for LM and $\geq 70 \%$ for others). In case of double vessel disease, lesion treated was classified according to the first lesion attempted (usually most complex or culprit lesion). Data regarding angiographic and procedural characteristics were recorded.

Follow up and clinical end points: Following the procedure patients were followed up till index hospitalization ( $4 \pm 2$ days after the procedure). Serum creatine kinase myocardial band levels were measured at baseline, 8 hours, 24 hours of procedure and daily recording of symptoms clinical examination and ECG were done. Following in-hospital adverse outcome were recorded.

Post procedural angina was defined as anginal chest pain or equivalent type of ischemic discomfort occurring at rest, on exertion or after meal and with or without evidence of transient ischemic changes in ECG or echocardiography. Acute MI due to stent thrombosis and other type of MI (according to universal MI definition) after 48 hours of procedure (except Coronary artery bypass graft- $\mathrm{CABG}$ related $\mathrm{MI}$ ) were included, and were diagnosed by elevated serum CK-MB level $>5 \mathrm{x} 99^{\text {th }}$ percentile of URL with any of subjective evidence of typical chest pain, ECG, echocardiography or angiography.

Periprocedural myocardial infarction was defined by elevation of CK MB values ( $>5 \times 99^{\text {th }}$ percentile URL) in patients with normal baseline values 
( $\leq 99$ th percentile URL) within 48 hours of PCI with either subjective evidence of typical chest pain or ECG or echocardiography or angiography. Periprocedural myocardial injury was diagnosed by elevated serum CK-MB level within 48 hours of PCI and not fulfilling criteria of periprocedural MI. Acute left ventricular failure was followed up clinically by Killip class and by doing echocardiography. Significant arrhythmia was defined as frequent ventricular ectopic, atrial fibrillation, ventricular tachycardia, ventricular fibrillation, second degree or third degree AV block. Cardiogenic shock was done for features of shock. Emergency revascularization was defined as, revascularization within 24 hours of the procedure. Death was defined as death from any cause during hospital stay.

Statistical analysis: Continuous baseline variables with normal distribution were expressed as mean \pm SD and were compared by t-test. Categorical variables were compared by Fisher's exact test or Chi-square test where appropriate. Correlation between hsCRP and rise of CK-MB was measured by Spearman's correlation coefficient test. Multiple logistic regression analysis was performed to establish the independent predictive value of pre-procedural high sensitivity C-reactive protein in addition to other traditional prognostic risk factors (control of confounding). The statistical analysis was performed using the Statistical Package for Social Sciences software (SPSS). A $p$-value $<0.05$ was considered statistically significant.

\section{Results}

A total of 200 patients based on predefined enrollment criteria were included in this study. Patients were divided into two groups according to the hsCRP level before percutaneous coronary intervention, of which 100 patients were included in Group I having preprocedural elevated hsCRP level ( $\geq 3 \mathrm{mg} / \mathrm{L})$ and 100 patients were included in Group II, having preprocedural normal hsCRP level $(<3 \mathrm{mg} / \mathrm{L})$. All patients were thoroughly observed after percutaneous coronary intervention during their post PCI hospital stay.

Baseline characteristics and hsCRP: The mean $( \pm \mathrm{SD})$ age of the patients was almost same in two groups with range of 35-70 years in Group I and 35-75 years in Group II. Most of the patients were in $7^{\text {th }}$ decades of life. Male sex predominat- ed in both groups with male-female ratio of 6.4:1. However, no significant difference was found between two groups in respect to age and sex.

Ischemic heart disease status, left ventricular ejection fraction, most of the angiographic and procedural characteristics of the study subjects were almost similar in two groups and the difference was not significant statistically.

Table I: Baseline characteristics of the study population $(n=100)$

\begin{tabular}{|c|c|c|c|}
\hline Variables & Group I & Group II & $p$ value \\
\hline Age $($ mean \pm SD $)$ & $55.38 \pm 9$ & $54.0 \pm 10.2$ & $0.31^{\mathrm{ns}}$ \\
\hline Female $\%$ & 15 & 12 & $0.53^{\text {ns }}$ \\
\hline BMI (mean $\pm \mathrm{SD})$ & $23.86 \pm 1.73$ & $23.43 \pm 2.69$ & $0.26^{\mathrm{ns}}$ \\
\hline Smoking \% & 68 & 66 & $0.76^{\mathrm{ns}}$ \\
\hline Hypertension \% & 54 & 58 & $0.56^{\mathrm{ns}}$ \\
\hline $\begin{array}{l}\text { Diabetes melli- } \\
\text { tus, } \%\end{array}$ & 42 & 40 & $0.77^{\mathrm{ns}}$ \\
\hline Dyslipidaemia \% & 45 & 48 & $0.39^{\text {ns }}$ \\
\hline $\begin{array}{l}\text { Family history of } \\
\text { premature } \\
\text { CAD } \%\end{array}$ & 10 & 4 & $0.10^{\mathrm{ns}}$ \\
\hline $\begin{array}{l}\text { Percentage of } \\
\text { residual steno- } \\
\text { sis,after PCI( } \\
\text { mean } \pm \text { SD) }\end{array}$ & $0.54 \pm 0.18$ & $0.70 \pm 0.21$ & $0.49^{\mathrm{ns}}$ \\
\hline $\begin{array}{l}\text { Length of } \\
\text { stent,mm } \\
(\mathrm{mean} \pm \mathrm{SD})\end{array}$ & $26.84 \pm 6.27$ & $26.96 \pm 7.12$ & $0.90^{\text {ns }}$ \\
\hline $\begin{array}{l}\text { Diameter of } \\
\text { stent, mm } \\
(\mathrm{mean} \pm \mathrm{SD})\end{array}$ & $2.72 \pm 0.23$ & $2.73 \pm 0.36$ & $0.92^{\mathrm{ns}}$ \\
\hline $\begin{array}{l}\text { Inflation pres- } \\
\text { sure, ATM } \\
(\text { mean } \pm \text { SD })\end{array}$ & $14.04 \pm 1.17$ & $13.72 \pm 0.99$ & $0.06^{\mathrm{ns}}$ \\
\hline $\begin{array}{l}\text { Duration of } \\
\text { inflation, } \\
\operatorname{Sec}(\text { mean } \pm S D)\end{array}$ & $27.50 \pm 4.43$ & D27.20 \pm 4.18 & $0.79^{\mathrm{ns}}$ \\
\hline BMS use \% & 73 & 70 & $0.64^{\mathrm{ns}}$ \\
\hline DES use\% & 27 & 30 & \\
\hline $\begin{array}{c}\text { Mean increase of } \\
\text { CK-MB } \\
(\text { mean } \pm \text { SD) }\end{array}$ & $33.06 \pm 16.62$ & $19.52 \pm 17.6$ & $0.005^{\mathrm{s}}$ \\
\hline
\end{tabular}

In-hospital events: Postprocedural angina was found in $17.0 \%$ patients in Group I and 6.0\% patients in Group II, and the difference was significant statistically $(p=0.01)$. Three percent of patients in Group I developed significant arrhythmia, which was $1.0 \%$ in Group II. Two percent patients developed acute left ventricular failure in Group I, whereas in Group II 1.0\% patient had acute left ventricular failure during post PCI hospital stay. Cardiogenic shock was observed in $2.0 \%$ patients in Group I and none of Group II. Four percent patients of Group I developed acute myocardial infarction and $2.0 \%$ patients died during the post PCI hospital stay. None of Group II developed acute MI or none expired. No patient underwent emergency revas- 
cularization in two groups. Differences of all the findings between two groups were not significant statistically $(p>0.05)$. Periprocedural MI was found in $6.0 \%$ patients in group I and $1.0 \%$ patient in Group II and the difference was significant statistically $(p=0.03)$. On the contrary, periprocedural myocardial injury was found in $10.0 \%$ patients of group I and $4.0 \%$ patients of Group II, which was also significant statistically $(p=0.04)$.

Table II: Comparison of in-hospital outcome between two groups $(\mathrm{n}=200)$

\begin{tabular}{|c|c|c|c|c|c|}
\hline \multirow[t]{2}{*}{$\begin{array}{l}\text { In-hospital } \\
\text { outcome }\end{array}$} & \multicolumn{2}{|c|}{$\begin{array}{l}\text { Group I }(\mathrm{n}= \\
\text { 100) }\end{array}$} & \multirow[t]{2}{*}{$\begin{array}{l}\text { Group } \\
\text { II }(\mathbf{n}= \\
100) \\
\text { Number }\end{array}$} & \multirow[b]{2}{*}{$\%$} & \multirow[t]{2}{*}{ p value } \\
\hline & $\begin{array}{l}\text { Num } \\
\text { ber }\end{array}$ & $\%$ & & & \\
\hline $\begin{array}{l}\text { Post proce- } \\
\text { dural } \\
\text { angina }\end{array}$ & 17 & 17.0 & 6 & 06.0 & $0.01^{\mathrm{s}}$ \\
\hline $\begin{array}{l}\text { Acute } \\
\text { myocardial } \\
\text { infarction }\end{array}$ & 4 & 4.0 & 0 & 0.0 & $0.12^{\mathrm{ns}}$ \\
\hline $\begin{array}{l}\text { Periproce- } \\
\text { dural MI }\end{array}$ & 6 & 6.0 & 1 & 1.0 & $0.04^{\mathrm{s}}$ \\
\hline $\begin{array}{l}\text { Periproce- } \\
\text { dural } \\
\text { myocardial } \\
\text { Injury }\end{array}$ & 10 & 10.0 & 4 & 4.0 & $0.03^{\mathrm{s}}$ \\
\hline $\begin{array}{l}\text { Acute left } \\
\text { ventricular } \\
\text { failure }\end{array}$ & 2 & 2.0 & 1 & 1.0 & $1.0^{\mathrm{ns}}$ \\
\hline Arrhythmia & 3 & 3.0 & 1 & 1.0 & $0.31^{\mathrm{ns}}$ \\
\hline $\begin{array}{l}\text { Cardiogen- } \\
\text { ic shock }\end{array}$ & 2 & 2.0 & 0 & 0.0 & $0.49^{\text {ns }}$ \\
\hline Death & 2 & 2.0 & 0 & 0.0 & $0.49^{\text {ns }}$ \\
\hline
\end{tabular}

Overall significant rate of major adverse cardiac events (MACE) were noted in high hsCRP.

Table III: Comparison of presence of Major Adverse Cardiac Events (MACE) between two groups $(n=200)$

\begin{tabular}{lcccccc}
\hline $\begin{array}{l}\text { Major Adverse Cardiac } \\
\text { (Death, AMI, emergency revascu- }\end{array}$ & $\begin{array}{c}\text { Group I } \\
(\mathrm{n}=100)\end{array}$ & \multicolumn{2}{c}{$\begin{array}{c}\text { Group II } \\
(\mathrm{n}=100)\end{array}$} & $p$ \\
larization) & Number & $\%$ & Number & $\%$ & \\
\hline Present & & 06 & 6.0 & 0.0 & 0.0 & $0.03^{\mathrm{s}}$ \\
Absent & 94 & 94.0 & 100 & 100 & \\
\hline
\end{tabular}

Although baseline CK-MB levels were same in both groups, post PCI CK-MB levels were higher in patients with elevated hsCRP level. The mean increase of CK-MB level following PCI was higher in elevated hsCRP(33.06 $\pm 16.62 \mathrm{U} / \mathrm{L}$ Vs. $19.52 \pm 17.60 \mathrm{U} / \mathrm{L}$ ) and the difference was significant statistically ( $p=0.005)$.Post PCI CK-MB rise was significantly higher in elevated hsCRP group. There was a weak linear positive correlation between the levels of preprocedural hsCRP and rise of CK-MB level( $\mathrm{r}=0.22, p=0.04)$

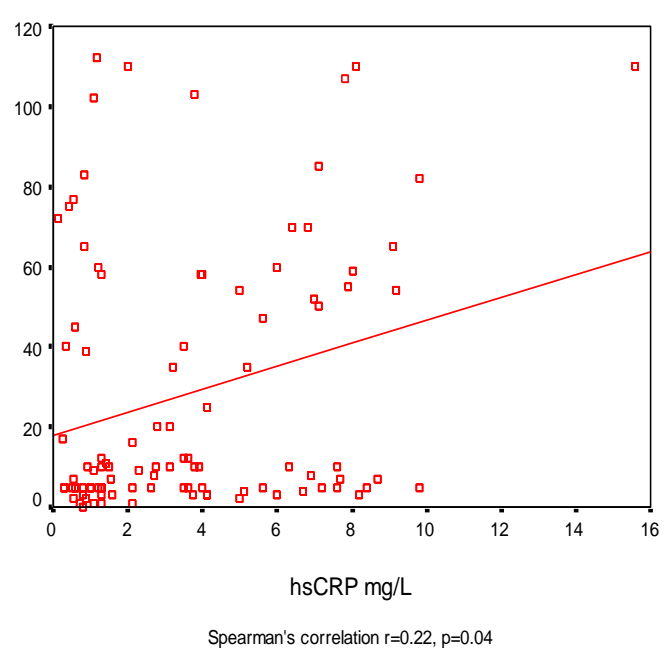

Figure 1: The scattered diagram shows significant relationship and correlation between pre procedural hsCRP and increased CK-MB level following PCI.

Binary logistic regression analysis of Relative Risk for predictors of adverse in-hospital outcome was done. The traditional risk factors for adverse in-hospital outcome were entered into the model directly by univariate and multivariate regression analysis. Elevated hsCRP was observed as an independent predictor for developing adverse in-hospital outcome $(p=0.001)$ and 95\% CI of RR being 1.4 - 4.4.

Table IV: Binary Logistic regression analysis for factors related to adverse in-hospital outcome

\begin{tabular}{lcccc}
\hline $\begin{array}{c}\text { Variables } \\
\text { of } \begin{array}{c}\text { inter- } \\
\text { est }\end{array}\end{array}$ & $\begin{array}{c}\text { Univariate } \\
\text { analysis } \\
\boldsymbol{p} \text { value }\end{array}$ & RR & $\mathbf{9 5 \%}$ CI of RR & p value \\
\hline $\begin{array}{l}\text { age }(\geq 60 \\
\text { years) }\end{array}$ & $0.62^{\mathrm{ns}}$ & 1.56 & $0.637-3.508$ & $0.17^{\mathrm{ns}}$ \\
$\begin{array}{l}\text { Female } \\
\text { gender }\end{array}$ & $0.39^{\mathrm{ns}}$ & 1.16 & $0.820-1.638$ & $0.50^{\mathrm{ns}}$ \\
$\begin{array}{l}\text { Diabetes } \\
\text { mellitus }\end{array}$ & $0.41^{\mathrm{ns}}$ & 0.86 & $0.644-1.259$ & $0.06^{\mathrm{ns}}$ \\
$\begin{array}{l}\text { Smoking } \\
\text { Increased }\end{array}$ & $0.90^{\mathrm{ns}}$ & 1.02 & $0.791-1.476$ & $0.29^{\mathrm{ns}}$ \\
$\begin{array}{l}\text { BMI } \\
\text { Type C }\end{array}$ & $0.81^{\mathrm{ns}}$ & 1.22 & $1.191-2.320$ & $0.05^{\mathrm{ns}}$ \\
lesion & & $0.740-1.466$ & $0.83^{\mathrm{ns}}$ \\
$\begin{array}{l}\text { Elevated } \\
\text { hsCRP }\end{array}$ & $0.001^{\mathrm{s}}$ & 2.54 & $1.461-4.420$ & $0.001^{\mathrm{s}}$ \\
\hline
\end{tabular}

\section{Discussion}

Patient demographics and anatomical characteristics (lesion complexity and number of diseased vessels) are currently used to define individual risk among patients undergoing PCI. ${ }^{1,2,11}$ Emerging evidence highlights the prognostic value of inflammatory markers such as CRP among patients with coronary artery disease. ${ }^{12,13}$ 
This analysis highlights the association between baseline CRP and post procedural events. This suggests that, baseline elevated hsCRP may predict risk of distal embolization, may augment micro vascular inflammation following PCI that might be responsible for post procedural complication. ${ }^{9}$ The present analysis documents that preprocedural CRP is an important independent prognostic indicator for in hospital outcome.

This study confirms and extends the findings from a small study by Bufflon et al in which increased preprocedural C-reactive protein was identified as an important predictor for early adverse outcome and late clinical restenosis in a series of 121 angioplasty. ${ }^{14}$

A nonsignificant increase in periprocedural death or MI was observed at 72 hours among patients with elevated baseline CRP in the c7E3 Fab Antiplatelet Therapy in Unstable Refractory Angina (CAPTURE) trial, reaching statistical significance by 30 days and 6 month. ${ }^{15}$ Factors possibly contributing to this marginal early excess risk include the higher, arbitrarily defined, dichotomous definition of elevated CRP $(1.0 \mathrm{mg} / \mathrm{dL})$, the relatively small study population, and the lack of coronary stenting within the present study. Nevertheless, an increased rate of death was noted at 30 days. Including patients from a more contemporary "stenting era" our large experience provides confirmatory evidence of the association between preprocedural CRP and 30day events. This analysis defines the independent association between elevated baseline CRP and 30-day death or MI while showing a significant increase in death alone, corroborating the CAPTURE experience.

Herrmann et al differ from our study regarding in hospital events. ${ }^{27}$ In that study, atherosclerotic burden and disease activity that determine longterm clinical outcomes after PCI rather than inflammation per se. But Preprocedural hsCRP level seems to be a marker of baseline risk and is independently associated with the risk of periprocedural MI. Findings does not support a role for routine measurement of hsCRP in the management of patients undergoing PCI in contemporary practice. ${ }^{27}$ Racial, ethnic variation, more use of DES and Glycoprotein IIb/IIIa inhibitor might be responsible for this.
Prior studies exploring the relationship between hsCRP and periprocedural MI have yielded conflicting results. ${ }^{16,20}$ In the present study, we explored this issue by applying the universal definition of periprocedural MI (type 4a) using a contemporary CK-MB assay to detect myonecrosis. ${ }^{21}$ Patients with elevated baseline CK-MB levels were not included because it is a challenge to diagnose periprocedural MI in these patients. A recent meta-analysis that found statin therapy to reduce periprocedural MI most prominently in patients with elevated pre-procedural CRP levels is subject to the same conundrum. ${ }^{22}$ Although these observations may relate to the association of hsCRP levels with epicardial coronary atherosclerosis activity and vulnerability, inflammation may equally impair coronary microvascular function and hence reduced myocardial tolerance to ischaemia. ${ }^{14,25,26}$ Periprocedural MI was found in $6(6.0 \%)$ patients of Group I and 1(1.0\%) in Group II, and the difference was significant statistically $(p<0.05)$. This finding consistent with study done by Herrmann et al. ${ }^{28}$ This relationship suggests that, CRP may predict the risk of distal embolization or may play a direct role in augmenting micro vascular inflammatory response after ischaemic insult.

In a recent meta-analysis, Patti et $\mathrm{al}^{22}$ showed that statin therapy reduced periprocedural MI, most prominently in patients with elevated preprocedural hsCRP level. Saadeddin et $\mathrm{al}^{17}$ reported that, pre-procedural hsCRP elevation in $41.0 \%$ of patients with stable angina and who underwent PCI, and this was associated with a 2.27 fold higher risk of developing periprocedural myocardial injury. Herrmann et $\mathrm{al}^{27}$ and Rhee et $\mathrm{al}^{28}$ also described similar result in their studies. Ten percent of Group I and 4.0\% of Group II had periprocedural myocardial injury in which CK-MB level was raised but less than five times of upper reference limit, or rise of CKMB >5 times of upper reference limit without chest pain, ECG, echocardiographic changes. Study considered cut off value of CK-MB more than three times of upper reference limit for diagnosis of periprocedural MI. ${ }^{30}$ This study considered periprocedural MI when post PCI CKMB level was more than five times of upper reference limit according to recent universal definition of MI guideline. ${ }^{22}$ If it could be considered that the previous CK-MB level for diagnosis of periprocedural MI, the incidence would be 
higher. Multivariate logistic regression analysis was done among traditional predictors of post PCI adverse outcome, such as advanced age $(>60$ years), female gender, diabetes mellitus, BMI, hypertension, smoking, type $\mathrm{C}$ lesion and hsCRP. Among these, high sensitivity CRP was an independent predictor for developing adverse inhospital outcome with 95\% CI of RR 1.4-4.4 and $p<0.001$. This correlates with the findings of Buffon et al ${ }^{14}$ Chew et al ${ }^{16}$ and Rhee et al. ${ }^{28}$

In this study, pre-procedural high hsCRP was associated with adverse in-hospital outcome following PCI. To date, robust supportive evidence has accumulated that, an elevated hsCRP level is associated with greater plaque instability and atherothrombosis, which may explain the worse prognosis. ${ }^{31}$

\section{Conclusion}

It might be concluded that, elevated pre-procedural hsCRP level is an important and independent predictor of adverse in-hospital outcome after percutaneous coronary intervention. Systemic inflammatory activity as measured by serum hsCRP level, might be more informative than classical risk factors predicting post PCI outcome. So, measurement of hsCRP level could provide a rationale for risk stratification before percutaneous coronary intervention. Although the results of this study supports the hypothesis, there are some facts which might affect the results. Hence, with larger sample size and multicentered study, evaluation of periprocedural MI through MRI thus recommended.

\section{References}

1. Califf RM, Abdelmeguid AE, Kuntz RE, Popma JJ, Davidson CJ, Cohen E, et al. Myonecrosis after revascularization procedures. J Am Col Cardiol. 1998; 31: 241-51.

2. Ellis SG, Vandormael MG, Cowley MJ, DiSciascio G, Deligonul U,Topol EJ, et al. Coronary morphologic and clinical determinants of procedural outcome with angioplasty for multivessel coronary disease: implications for patient selection: Multivessel Angioplasty Prognosis Study Group. Circulation. 1990; 82: 1193-1202.

3. Ellis SG, Guetta V, Miller D, Whitlow PL, Topol EJ. Relation between lesion characteristics and risk with percutaneous intervention in the stent and glycoprotein IIb/IIIa era: an analysis of results from 10,907 lesions and proposal for new classification scheme. Circulation.1999; 100:1971-76.
4. Pietersma A, Kofflard M, Dewit EA. Late luminal loss after coronary angioplasty is associated with the activation status of circulating phagocytes before treatment. Circulation. 1995; 91:1320-25.

5. Ikeda U, Ikeda M, Oohara T. Interleukin-6 stimulates the growth of vascular cells in a PD GFdependent manner. Am J Physiol. 1991; 260: 1713-17.

6. Zebrack JS, Anderson JL, Maycock CA, Horne BD, Bair TL, Muhlestein JB.Usefulness of highsensitivity C-Reactive protein in predicting longterm risk of death or acute myocardial infarction in patients with unstable or stable angina pectoris or acute myocardial infarction. Am $\mathbf{J}$ Cardiol. 2002; 89(2):145-49.

7. Abbate A, Biondi-Zoccai GGL, Brugaletta S, Liuzzo G, Biasucci LM. C-reactive protein and other inflammatory biomarkers as predictors of outcome following acute coronary syndrome. Seminar on Vascular Med. 2003; 3: 377-79.

8. Kishimoto T, Akira S, Narazaki M, Taga T, 1995. Interleukin- 6 family of cytokines and gp130. Blood 1995;86:1243-54.

9. Pasceri V, Willerson JT, Yeh ET. Direct proinflammatory effect of C-reactive protein on human endothelial cells. Circulation. 2000; 102: 2165-68.

10. Chan AW, Bhatt DL, Chew DP, Reginelli J, Schneider JP, Topol EJ, et al. Relation of Inflammation and Benefit of Statins After Percutaneous Coronary Intervention. Circulation 2003; 107:1750-56.

11. Tan K, Sulke N, Taub N, Sowton E. Clinical and lesion morphologic determinants of coronary angioplasty success and complications: current experience. J Am Col Cardiol. 1995; 25:855-65.

12. Lagrand WK, Visser CA, Hermens WT, Niessen HWM, Verheugt FWA,Wolbink GJ, et al. CReactive Protein as a Cardiovascular Risk Factor. More Than an Epiphenomenon? Circulation. 1999; 100:96 -102.

13. Ridker PM, Hennekens CH, BuringJE, Rifai N. Creactive protein and other markers of inflammation in the prediction of cardiovascular disease in women. N Engl J Med. 2000.342; 836- 43.

14. Buffon A, Liuzzo G, Biasucci LM, Pasqualetti P, Ramazzotti V, Rebuzzi AG. Preprocedural serum levels of C-reactive protein predict early complications and late restenosis after coronary angioplasty. JAm Col Cardiol. 1999;34:1512-21.

15. Heeschen C, HammCW, Bruemmer J, Simoons ML. Predictive value of $\mathrm{C}$-reactive protein and troponin $\mathrm{T}$ in patients with unstable angina: a comparative analysis, Capture investigators. Chimeric c7E35 antiplatelet therapy in unstable angina refractory to 
standard treatment trial. J Am Col Cardiol. 2000; 35:1535-42.

16. Chew DP, Bhatt DL, Robbins MA, Penn MS, Schneider JP, Lauer MS. Incremental prognostic value of elevated baseline $\mathrm{C}$-reactive protein among established markers of risk in percutaneous coronary intervention. Circulation. 2001; 104: 992-97.

17. Saadeddin SM, Habbab MA, Sobki SH, Fern GA Association of systemic inflammatory state with troponin I elevation after elective uncomplicated percutaneous coronary intervention. Am J Cardiol. 2002; 89:981-83.

18. Goldberg A, Gruberg L, Roguin A, Petcherski S, Rimer D, Markiewicz W et al. Preprocedural Creactive protein levels predict myocardial necrosis after successful coronary stenting in patients with stable angina. A H J. 2006; 151:1265-70.

19. Delhaye C, Maluenda G, Wakabayashi K, Itsik BenDor, Lemesle G, Collins SD, et al. Long-term prognostic value of preprocedural C-reactive protein after drug-eluting stent implantation. Am J Cardiol. 2010; 105:826-32.

20. Veselka J, Prochazkova S, Duchonova R, Homolova I, Tesar D. Relationship of C-reactive protein to adverse cardiovascular events in patients treated by percutaneous coronary intervention for stable angina pectoris. Int Heart J 2005; 46: 195-204.

21. Thygesen K, Alpert JS, Jaffe AS. The Writing Group on behalf of the Joint ESC/ACCF/AHA/WHF Task Force for the Universal Definition of Myocardial Infarction. Third universal definition of myocardial infarction. Circulation 2012; 126:2020-35.

22. Patti G, Cannon CP, Murphy SA, Mega S, Pasceri $\mathrm{V}$, Briguori $\mathrm{C}$, et al. Clinical benefit of statin pretreatment in patients undergoing percutaneous coronary intervention: a collaborative patient-level metaanalysis of 13 randomized studies, Circulation. 2011; 123:1622-32.
23. Herrmann J. Peri-procedural myocardial injury: 2005 update. Eur Heart J. 2005; 26:2493-2519.

24. Schwedler SB, Kuhlencordt PJ, Ponnuswamy PP, Hatiboglu G,Quaschning T,WidderJ, et al.Native Creactive protein induces endothelial dysfunction in ApoE-/- mice: implications for iNOS and reactive oxygen species. Atherosclerosis. 2007; 195:e76-e84.

25. Teragawa H, Fukuda Y, Matsuda K, Ueda K, Higashi $\mathrm{Y}$, Oshima $\mathrm{T}$, et al. Relation between $\mathrm{C}$ reactive protein concentrations and coronary microvascular endothelial function. Heart. 2004; 90:750-54.

26. Tomai F, Crea F, Gaspardone A, Versaci F, Ghini AS, Chiariello L, et al. Unstable angina and elevated C reactive protein levels predict enhanced vasoreactivity of the culprit lesion. Circulation. 2001; 104:147176.

27. Herrmann J, Lennon RJ, Gregory W, Barsness GW, Sandhu GS, Gulati R, et al. High Sensitivity CReactive Protein and Outcomes Following Percutaneous Coronary Intervention in Contemporary Practice. Circ Cardiovascular Interv. 2012; 5:783-90.

28. Rhee SJ, Yun KH,Oh SK,Park EM,Lee EM,Yoo NJ, et al. Changes of C-reactive protein are Associated with Myocardial Injury after Successful Percutaneous Coronary Intervention. Korean Circ J. 2008; 38:135-39.

29. Balian V, Galli M, Marcassa C, Cecchin G, Child M, Barlocco F,et al. Intracoronary ST-segment shift soon after elective percutaneous coronary intervention accurately predicts periprocedural myocardial injury. Circulation. 2006; 114:1948-54.

30. Tsimikas S, Willerson JT, Ridker PM. C-reactive protein and other emerging blood biomarkers to optimize risk stratification of vulnerable patients. J Am Col Cardiol. 2006; 47:C19-31. 